\title{
Analysis of General Composition and Harmful Material of Protaetia brevitarsis
}

\author{
Mi Yeon Chung, Jae-Sam Hwang, Tae-Won Goo and Eun-Young Yun*
}

Department of Agricultural Biology, National Academy of Agricultural Science, RDA, Suwon 441-100, Korea

Received March 7, 2013 /Revised May 6, 2013 /Accepted May 7, 2013

\begin{abstract}
To evaluate Protaetia brevitarsis as a food material, we investigated its composition of nutritional and harmful components. Analysis of nutritional composition (moisture, crude protein, crude fat, crude ash, crude fiber, and carbohydrates) showed that the content of crude protein, fat, fiber, and ash were $57.86 \pm 0.01 \%, 16.57 \pm 1.81 \%, 5.31 \pm 0.10 \%$, and $8.36 \pm 0.10 \%$ in Protaetia brevitarsis powder, respectively. Amino acids were composed of $17.68 \%$ essential and $33.97 \%$ non-essential in Protaetia brevitarsis powder. Protaetia brevitarsis powder contained $61.10 \%$ unsaturated fatty acid with oleic acids. Additionally, Protaetia brevitarsis powder had a large quantity of minerals related to body organization, such as K (1597 mg/100 g), P (724.1 mg/100 g), Mg (366.3 mg/100 g), and so on. We also confirmed that all bacteria and all heavy metals analyzed in this study, except for very small amount of $\mathrm{Hg}$ $(0.1 \pm 0.042 \mathrm{mg} / \mathrm{kg})$, were not detected in the lysophilized Protaetia brevitarsis powder.
\end{abstract}

Key words : Protaetia brevitarsis, food, nutritional composition, harmful material

\section{서 론}

최근 식생활의 서구화와 의학의 발달 등으로 평균수명이 증가하여 고령화 사회가 도래하였으며 이에 따라 각종 난치 성 질병 및 만성 퇴행성 질환이 급속도로 증가되고 있다. 이 러한 질병의 예방 및 치료를 위해 식생활의 변화 및 건강보 조식품과 영양 보충제 등 2차 먹거리에 대한 관심이 날로 증 대되고 있는 실정이다. 이러한 측면에서 일반적으로 단백질, 불포화 지방산 및 미네랄이 다량 함유되어 있는 고급 단백질 공급원으로 알려져 있는 곤충자원에 대한 식 - 약용 소재화 를 위한 연구들이 많이 이루어지고 있으며[3], 특히 나비목 (Lepidoptera), 딱정벌레목(Coleoptera), 메뚜기목(Orthoptera), 흰개미목(Isoptera) 및 벌목(Hymenoptera) 등이 식용곤충 (edible insect)으로 현재에도 민간에서 이용되고 있다.

흰점박이꽃무지(white-spotted flower chafer, Protaetia brevitarsis)는 딱정벌레목 꽃무지과로 분류되는 완전변태곤충으 로서 주로 한국, 일본, 대만, 중국, 유럽에 분포하고 있다. 몸 길이가 약 $17 \sim 24 \mathrm{~mm}$ 의 식식성(食植性) 곤충으로 성충은 야 외에서 7월 상순부터 출현하여 8월 상순에 가장 출현빈도가 높으며 $[7,10]$, 유충은 미생물에 의해 발효된 참나무톱밥과 같 은 부엽토 속에서 서식하여 10월 하순까지 3령 유충으로 변태 후 월동에 들어간다[6]. 예로부터 한의학에서 흰점박이꽃무지

\section{*Corresponding author}

Tel : +82-31-290-8576, Fax : +82-31-290-8543

E-mail : yuney@korea.kr

This is an Open-Access article distributed under the terms of the Creative Commons Attribution Non-Commercial License (http://creativecommons.org/licenses/by-nc/3.0) which permits unrestricted non-commercial use, distribution, and reproduction in any medium, provided the original work is properly cited.
유충을 굼벵이 또는 제조(蟀螬)라고 하였으며, 주로 간장병, 아구창, 파상풍, 이뇨작용 등에 이용하여 왔으며[5], 현재에도 한국식품의약품안전청(Korea Food \& Drug Administration, $\mathrm{KFDA}$ )의 생약 데이터베이스에 등록되어 약용으로는 이용이 가능하나, 식품공전에 등록되지 않았으므로 식용으로는 사용 이 불가능하다. 현재까지 식품공전에 등록된 곤충으로는 누에 (Bombyx mori)와 벼메뚜기(Oxya chinensis Sinuosa)만이 있으 므로 이 두 가지 곤충은 식품으로 제조 및 판매 가능하나 그 외 곤충은 불가능한 상태이다.

따라서 누에와 메뚜기를 제외한 곤충을 식용으로 사용하기 위해서는 2010년부터 식약청에서 시행하고 있는 '한시적 인정 제도'에 따라 '새로운 식품원료의 안전성 평가 가이드라인'에 부합되는 새로운 식품원료의 안전성 등을 평가한 후 식약청에 한시적 인정을 받아야 식품으로 사용 가능하므로 식약청의 기준에 부합되는 원료의 일반성분분석 및 유해성 검사를 통해 안전성을 확보하는 것이 무엇보다 시급한 실정이다. 그러므로 본 연구에서는 흰점박이꽃무지의 식품소재화 연구의 일환으 로 원료의 주요 영양성분 및 유해물질 분석을 통해 흰점박이 꽃무지의 새로운 식품원료로써의 영양적 가치 및 안전성에 대한 기초자료로 활용하고자 하였다.

\section{재료 및 방법}

\section{실험재료}

흰점박이꽃무지의 3 령 유충을 스머프 곤충나라(남양주, 경 기도)로부터 확보한 후, 먹이원(사료)을 제거하고 3 일 동안 절 식상태로 배변을 유도하였다. 유충을 흐르는 물에 2회 세척한 후 자연 건조하여 물기를 제거한 다음 $115^{\circ} \mathrm{C}, 0.9 \mathrm{kgf} / \mathrm{cm}^{2}$ 로 5 분간 고온고압멸균하고 $-80^{\circ} \mathrm{C}$ 에서 24 시간 이상 동결 후, 동결 
건조기(Eyela, Japan)에서 약 $48 \sim 60$ 시간 동안 건조하였다. 건 조된 유충은 분쇄기를 이용하여 분쇄하여 분말을 제조하였고, $-80^{\circ} \mathrm{C}$ 에 보관하며 분석 시료로 사용하였다.

\section{일반성분분석}

동결 건조된 흰점박이꽃무지 유충의 일반성분은 공인분석 화학자협회(Association of Official Analytical Chemists, $\mathrm{AOAC})[1]$ 의 기준에 준하여 분석하였다. 즉 수분 함량은 10 $5^{\circ} \mathrm{C}$ 상압건조법, 회분함량은 $550^{\circ} \mathrm{C}$ 직접회화법을 이용하여 분 석하였으며, 조단백함량은 micro-Kjeldahl법을 이용한 질소정 량법, 조지방함량은 ether 추출법에 따라 성분 함량을 측정하 였다.

\section{아미노산 조성 분석}

아미노산 분석을 위하여 동결 건조된 흰점박이꽃무지 유충 의 분말 $5 \mathrm{~g}$ 과 $6 \mathrm{~N} \mathrm{HCl} 40 \mathrm{ml}$ 을 둥근 플라스크에 넣고 혼합한 다음 $110^{\circ} \mathrm{C}$ 에서 24 시간 동안 질소가스를 주입하여 가수분해 하였다. 염산을 $50^{\circ} \mathrm{C}$ 에서 감압 농축시킨 다음 농축시료는 0.2 $\mathrm{N}$ sodium citrate buffer (pH 2.2) $50 \mathrm{ml}$ 을 넣어 희석시키고 여과지 $(0.45 \mu \mathrm{m})$ 로 여과하였다. 여과한 시료 $(30 \mu \mathrm{ll})$ 는 아미노 산 분석기(L-8900, Japan)를 이용하여 분석하였다.

\section{지방산 조성 분석}

동결 건조된 흰점박이꽃무지 유충 분말의 지방산 분석은 2:1(v/v)로 chloroform과 methanol을 섞은 용액으로 추출하 였고[2, 4], 가수분해하여 gas chromatography (US/HP 6890, Aglient Technologies, Korea)를 사용하여 분석하였다. Gas chromatography (GC) 조건은 silica capillary column (Omegawax 205, $0.25 \mu \mathrm{m}$ film thickness)을 이용하였고 injection port 온도는 $250^{\circ} \mathrm{C}$ 였으며 검출기 온도는 $260^{\circ} \mathrm{C}$ 로 유지 하였다.

\section{무기질 조성 분석}

흰점박이꽃무지 유충 체내의 미량 원소 분석을 위해 동결 건조된 흰점박이꽃무지 유충 분말의 $5 \mathrm{~g}$ 을 예비 회화시킨 후 $600^{\circ} \mathrm{C}$ 의 전기로에서 2시간 이상 회화시키고 염산용액(1:1)을 첨가하여 하룻밤 동안 방치 및 용해하였다. 용해된 시료를 No. 6 여과지로 여과한 후 시료로 사용하였다. 무기물분석은 inductively coupled plasma optical emission spectrometer (IC-OES, Horiba, Japan)를 이용하여 무기물인 구리(Cu) $324.754 \mathrm{~nm}$, 마그네슘 $(\mathrm{Mg}) 279.353 \mathrm{~nm}$, 망간 $(\mathrm{Mn}) 257.610 \mathrm{~nm}$, 인(P) $213.618 \mathrm{~nm}$, 아연 $(\mathrm{Zn}) 213.856 \mathrm{~nm}$, 철 $(\mathrm{Fe}) 259.940 \mathrm{~nm}$, 칼슘 $(\mathrm{Ca}) 393.366 \mathrm{~nm}$, 칼륨 $(\mathrm{K}) 769.896 \mathrm{~nm}$ 로 측정하였다.

\section{유해물질 분석}

동결 건조된 흰점박이꽃무지 유충의 안전성 확인을 위해
식품공전의 규정에 따라 식중독균(Escherichia coli $\mathrm{O} 157: \mathrm{H7}$, Salmonella spp.)의 존재 유무와 중금속 검사를 실시하였다. 대 장균 $\mathrm{O} 157: \mathrm{H7}$ (E. coli $\mathrm{O} 157: \mathrm{H7})$ 의 검사를 위해서 시료 $25 \mathrm{~g}$ 을 $\mathrm{mEC}$ 배지(EC broth, Novobiocin Supplement, Thermo Fisher Scientific, UK) $225 \mathrm{ml}$ 에 넣어 $36 \pm 1^{\circ} \mathrm{C}$, 24시간 동안 증 균 배양 후, 배양액을 cefixime과 potassium tellurite를 첨가한 MacConkey Sorbitol 한천배지(Sorbitol MacConkey Agar, Thermo Fisher Scientific, UK)에 접종하였다. 무색 집락으로 확인된 집락을 $\mathrm{EMB}$ 한천배지에 접종 후, $36 \pm 1^{\circ} \mathrm{C}$, 24 시간 동안 배양하였다. 대장균으로 추정되는 보라색 집락을 보통한천배 지에 접종하여 순수 배양하여 그람염색법과 $\mathrm{O} / \mathrm{H}$ 혈청형 시 험법을 이용하여 분석하였다. 살모넬라균(Salmonella spp.)은 시료 $25 \mathrm{~g}$ 을 peptone water $225 \mathrm{ml}$ 에 넣어 $36 \pm 1^{\circ} \mathrm{C}, 24$ 시간 동안 배양한 후, 배양액 $0.1 \mathrm{ml}$ 을 Rappaport-Vassiliadis 배지 $10 \mathrm{ml}$ 에 접종하고 $42 \pm 1^{\circ} \mathrm{C}, 24$ 시간 동안 배양하였다. XLD 한천 배지에 접종 후 집락의 중앙 부분이 검거나 붉으면 보통한천 배지에 접종하여 $36 \pm 1^{\circ} \mathrm{C}, 24$ 시간 동안 배양하고 TSI 한천배지 (Triple Sugar Iron Agar, Thermo Fisher Scientific, UK)에 접 종 후, 살모넬라(Salmonellaspp.)로 의심되는 성상 여부를 관찰 하였다. 살모넬라로 의심 될 경우, 그람염색법과 살모넬라 (Salmonella spp.) O/H 혈청 응집 시험법을 이용하여 분석하였 다. 중금속 분석은 inductively coupled plasma optical emission spectrometer (IC-OES, Horiba, Japan)를 이용하여 측정 하였고, 원소별 측정 파장은 납 $(\mathrm{Pb}) 220.353 \mathrm{~nm}$, 수은 $(\mathrm{Hg})$ $194.227 \mathrm{~nm}$, 비소(As) $193.696 \mathrm{~nm}$, 카드뮴(Cd) $228.802 \mathrm{~nm}$ 로 측정하였다.

\section{결과 및 고찰}

\section{흰점박이꽃무지 유충의 일반성분 및 식이섬유소 함량}

본 연구에서 분석한 흰점박이꽃무지 유충 분말 $100 \mathrm{~g}$ (dry weight basis) 중에는 조단백질의 함량이 $57.86 \pm 0.01 \%$ 로 가장 높았으며, 조지방 $16.57 \pm 1.81 \%$, 조회분 $8.36 \pm 0.10 \%$ 가 함유되 어 있었고 총 식이섬유소 함량은 $5.31 \pm 0.10 \%$ 로 측정되었다 (Table 1). 일반적인 단백질 식품의 단백질 함량은 난류 $8.5 \sim 14.4 \%$, 육류 15.2 34.7\%, 어류 10.4 47.7\% 이므로 흰점박 이꽃무지의 단백질함량이 매우 높은 편임을 알 수 있었다. 이 는 현재 식용곤충으로 허가된 누에(55 76\%)와 메뚜기(68 $78 \%)$ 의 단백질 함량과 유사하였으므로[5] 흰점박이꽃무지를 고단백질 식품소재로 이용 가능할 것으로 사료된다.

\section{아미노산 조성 분석}

흰점박이꽃무지 유충의 일반성분분석 결과 일반성분 중 조 단백질 함량이 $57.86 \pm 0.01 \%$ 로 가장 높은 비율을 차지하고 있 음을 알 수 있었고, 이 중 대표적인 17종의 구성아미노산의 함량 분석을 실시하였다. 그 결과 흰점박이꽃무지의 구성 아 
Table 1. General components of freeze-drying Protaetia brevitarsis powder $(\%)(\mathrm{n}=2)$

\begin{tabular}{cc}
\hline General component & P. brevitarsis \\
\hline Moisture & $6.66 \pm 6.40$ \\
Crude protein & $57.86 \pm 0.01$ \\
Crude fat & $16.57 \pm 1.81$ \\
Crude ash & $8.36 \pm 0.10$ \\
Crude fiber & $5.31 \pm 0.10$ \\
Total Carbohydrate $^{1)}$ & $10.56 \pm 4.49$ \\
\hline
\end{tabular}

${ }^{1)}$ Total Carbohydrate: 100-(moisture+crude protein+crude fat + crude ash)

Values are mean \pm S.D.

미노산은 필수아미노산 $17.68 \%$ 과 비필수아미노산 $33.97 \%$ 으 로 구성되었음을 확인할 수 있었다. 필수아미노산인 methionine, threonine, valine, isoleucine, leucine, phenylanine, histidine 및 lysine은 몸의 균형을 유지하고 성장에 필수적인 것 으로 체내에서 합성할 수 없어 반드시 음식으로써 섭취해야 한다. 흰점박이꽃무지 유충의 경우 이들 필수아미노산이 다량 함유되어 있으며 그 중 알레르기 증상을 완화시키며 혈액 생 성을 돕는 등 유아기에 있어 필수아미노산으로 분류되어 있는 histidine이 $3.37 \%$ 로 가장 많이 함유되어 있었다(Fig. 1A). 또 한 생체조직 성장과 근육세포 재생에 필수적인 역할을 하며 신진대사 촉진 역할을 수행하며 음식으로 섭취되지 않아 체내 에서 합성이 가능한 비필수아미노산인 cystein, asparatic acid, serine, glutamic acid, glycine, alanine, tyrosin, arginine 및 proline의 함량을 분석한 결과 인지능력 개선 및 기억력 향상 에 도움을 주는 glutamic acid가 $7.57 \pm 0.28 \%$ 로 가장 많이 함유 되어 있었으며, 콜라겐 생성에 도움을 주어 연골형성을 돕는 다고 알려져 있는 proline이 $5.55 \%$ 로 확인되었다(Fig. 1B). 국 내 식품의약품안전청(Korea Food \& Drug Administration, $\mathrm{KFDA})$ 에 식용으로 인정하고 있는 누에(Bombyx mori)의 경우 glycine, alanine, arginine, serine, aspartic acid는 알코올성 간독성 관련 연구에서 간 질환을 개선하는 효과가 있다고 알 려져 있다 $[8,11]$. 따라서 필수 및 비필수 아미노산이 풍부히 함유되어 있는 흰점박이꽃무지 유충의 경우에도 다양한 기능 성을 보유하여 건강증진까지 기대할 수 있는 식품소재로 개발 될 수 있을 것이라 판단된다.

\section{지방산 조성 분석}

흰점박이꽃무지 유충 분말의 전체 지방산 함량 중 불포화지 방산이 $73.83 \%$, 포화지방산은 $21.70 \%$ 으로 불포화지방산의 함 량이 매우 높게 확인되었다. 흰점박이꽃무지의 포화지방산을 구성하는 myristic acid (C14:0), palmitic acid (C16:0), stearic acid (C18:0)을 분석한 결과, palmitic acid (C16:0), steraric acid (C18:0), myristic acid (C14:0)의 순서로 각각 17.74 $\pm 0.22 \%, 3.05 \pm 0.72 \%, 0.71 \pm 0.12 \%$ 로 함유되어 있었다. 불포화
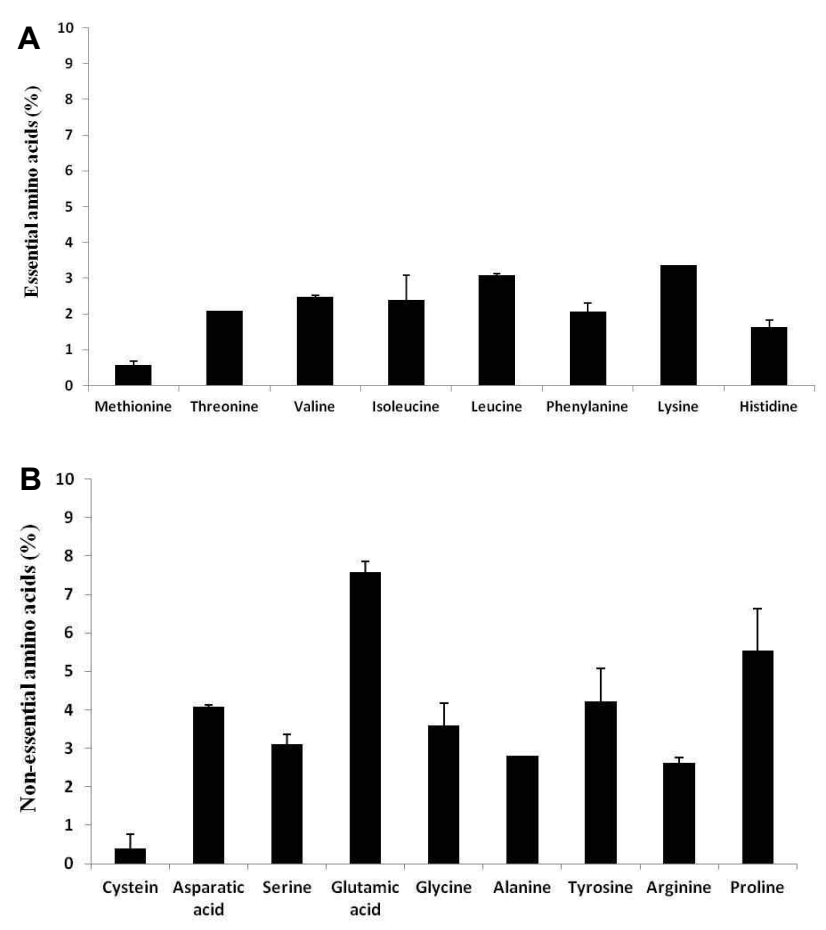

Fig. 1. Essential (A) and non- essential amino acid (B) contents of $P$. brevitarsis larvae. The values showed as means $\pm \mathrm{SD}$ $(\mathrm{n}=2)$.

지방산을 구성하는 palmitoleic acid (C16:1n7), oleic acid (C18:1n9), linoleci acid (C18:2n6), $\gamma$-linoleic acid (C18:3n6), linolenic acid (C18:3n3), eicosenoic acid (C20:1n9), arachidonic acid (C20:4n6), eicosapentaenoic acid (EPA, C20:5n3), docosahexaenoic acid (DHA, C22:6n3)를 분석한 결과, oleic acid (C18:1n9)가 $61.10 \pm 4.53 \%$ 로 가장 높게 측정되었으며, 다 음으로 palmitoleic acid (C16:1n7), linoleic acid (C18:2n6)가 각각 $9.55 \pm 1.79 \%, 5.22 \pm 1.71 \%$ 로 측정되었고, arschidonic acid (C20:1n9)가 $0.25 \pm 0.02 \%$ 로 미량 측정되었다(Fig. 2). 가장 많은 양을 차지하는 불포화 지방산으로 oleic acid의 경우 혈중의 고밀도 지질 단백질(high density lipoprotein, HDL)의 함량을 높이고 저밀도 지질 단백질(low density lipoprotein, $\mathrm{LDL}$ )의 함량을 낮추며 콜레스트롤 수치를 정상화 시켜, 혈관계 질환 을 예방할 수 있는 기능을 가진다고 보고된 바 있으며 $[9,12]$. 이들 불포화 지방산의 경우 인체의 성장과 유지를 위한 필수 지방산으로 체내에서 합성되지 않아 반드시 음식을 통해서 섭취 되어야 한다. 흰점박이꽃무지 유충 내의 고함량의 불포 화지방산과 미량의 필수지방산의 확인을 통해서 흰점박이꽃 무지를 육류나 어류의 섭취를 대신할 수 있는 식품으로서 사 용 가능할 것으로 추정된다.

\section{무기질 조성 분석}

흰점박이꽃무지 유충의 무기질과 비타민 함량을 분석한 결 


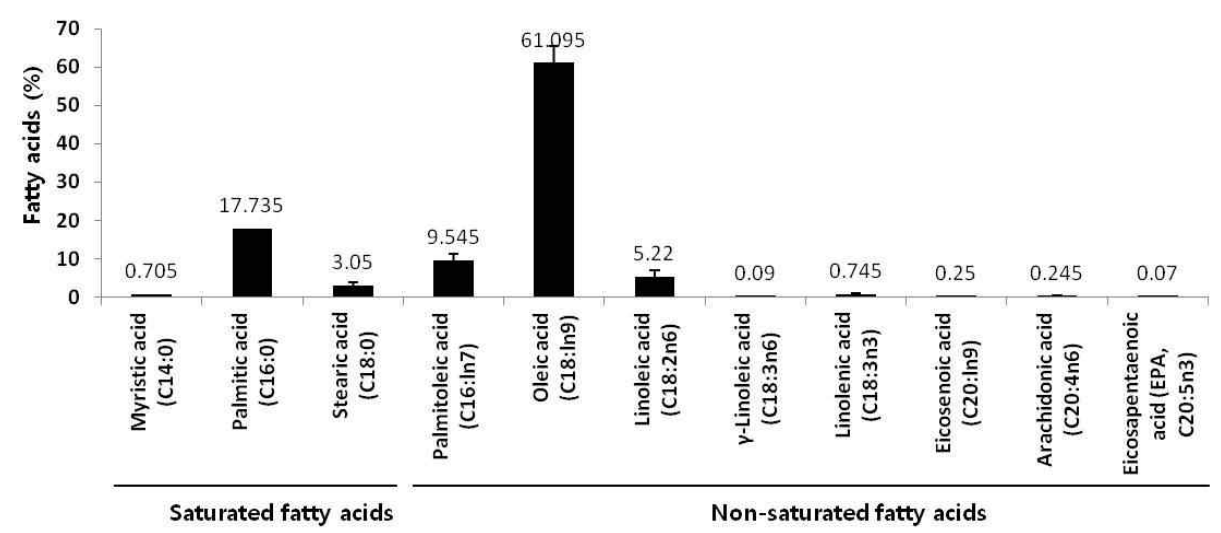

Fig. 2. Fatty acid compositions of Protaetia brevitarsis larvae. The values showed as means \pm SD ( $n=2)$.

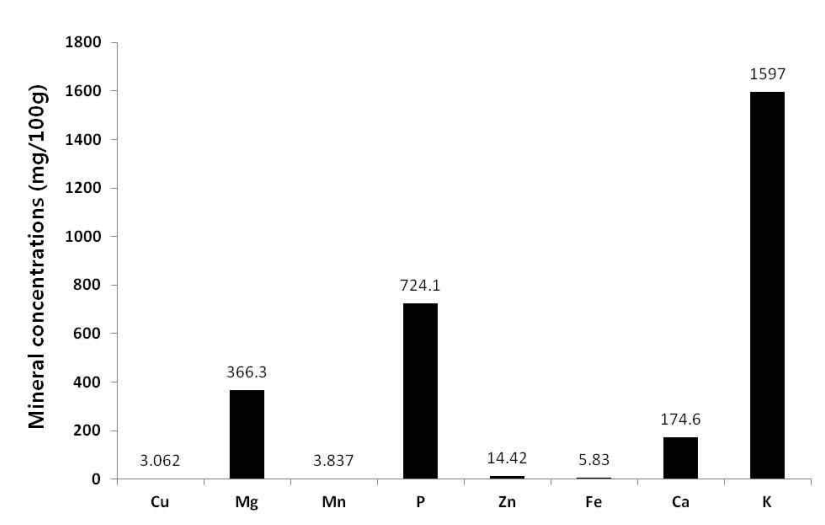

Fig. 3. Minerals contents of Protaetia brevitarsis larvae.

Table 2. Harmful substance of freeze-drying Protaetia brevitarsis powder $(n=2)$

\begin{tabular}{ccc}
\hline $\begin{array}{c}\text { Hazardous } \\
\text { substance }\end{array}$ & Content & P. brevitarsis \\
\hline & Lead $(\mathrm{Pb})$ & $0.70 \pm 0.49 \mathrm{mg} / \mathrm{kg}$ \\
Heavy & Mercury (Hg) & $0.1 \pm 0.042 \mathrm{mg} / \mathrm{kg}$ \\
metals & Arsenic (AS) & $\mathrm{ND}^{1)}$ \\
& Cadmium (Cd) & $\mathrm{ND}^{1)}$ \\
\hline Food & Escherichia coli $(\mathrm{O} 157: \mathrm{H} 7)$ & $\mathrm{ND}^{1)}$ \\
poisoning & Salmonella spp. & $\mathrm{ND}^{1)}$ \\
bacteria & Aerobic plate count & $\mathrm{ND}^{1)}$ \\
\hline
\end{tabular}

${ }^{11} \mathrm{ND}$ : Not Detected, Values are mean \pm S.D

과, 건조시료 $100 \mathrm{~g}$ 당 체내 조직 형성에 관여하는 칼륨 $(\mathrm{K})$, 인 (P) 및 마그네슘 $(\mathrm{Mg})$ 의 함량이 각각 $1579 \mathrm{mg}, 724.1 \mathrm{mg}$ 그리 고 $366.3 \mathrm{mg}$ 으로 높게 측정되었고(Fig. 3), 신경전달물질을 생 산하며 피부 수분유지기능이 알려져 있는 Vitamin B3의 함량 이 $8.810 \mathrm{mg} / 100 \mathrm{~g}$ 측정되었다(Table 3). 무기질은 체내의 여 러 생리기능의 조절 및 유지에 중요한 역할을 수행하는데 흰 점박이꽃무지 유충의 경우 체내에서 합성할 수 없는 무기물이 풍부하므로 흰점박이꽃무지 유충이 유익한 식품소재로의 활 용 가치가 높을 것이라 생각된다.
Table 3. Vitamine concentration of freeze-drying Protaetia brevitarsis powder

\begin{tabular}{lc}
\hline Vitamin & Concentration $(\mathrm{mg} / 100 \mathrm{~g})$ \\
\hline Vitamin A & $\mathrm{ND}^{1)}$ \\
Vitamin C & $\mathrm{ND}^{1)}$ \\
Vitamin D & $\mathrm{ND}^{1)}$ \\
Vitamin E & $\mathrm{ND}^{1)}$ \\
Vitamin B6 & $\mathrm{ND}^{1)}$ \\
Vitamin B3 & 8.81 \\
Vitamin B5 & 4.26 \\
\hline
\end{tabular}

${ }^{1)} \mathrm{ND}$ : Not Detected.

\section{유해물질 분석}

흰점박이꽃무지 유충의 식 - 약용 소재화를 위해서는 유해 물질 분석이 필수적이므로 이를 위해 납, 수은, 비소, 카드뮴에 대한 중금속 검사와 벤조피렌을 포함한 유해물질 검사를 실시 하였다. 그 결과 검사대상 중금속 중 수은의 함량이 $0.1 \mathrm{mg} / \mathrm{kg}$ 이 검출되었으나 일반식품허용기준(어패류 $0.5 \mathrm{mg} / \mathrm{kg}$ ) 이하 의 수준으로 확인되었다. 반면 벤조피렌을 포함한 유해물질 및 중금속 등은 전혀 검출되지 않아 그 안전성이 높게 평가되 었다(Table 2). 또한 식품공전 규정에 따른 병원성 미생물인 대장균 $(E . c o l)$ 과 salmonella spp.의 PCR 기법을 이용한 정성분 석 결과, 흰점박이꽃무지 유충 분말에서 병원성 미생물은 전 혀 검출되지 않았다(Table 2). 따라서 이러한 결과들을 통해 흰점박이꽃무지 유충의 중금속 및 유해성분으로부터의 안전 성이 확인되었으며 흰점박이꽃무지 유충이 식 - 약용으로서 의 활용 가능성이 매우 높을 것으로 기대된다.

\section{감사의 글}

본 연구는 농림수산식품부에서 지원하는 2011년도 생명산 업기술개발사업(311006-3)의 연구수행으로 인한 결과물임을 밝힙니다. 


\section{References}

1. AOAC. 1990a. Association of Official Analytical chemists. Official Methods of Analysis $15^{\text {th }}$ eds., Washington, DC.

2. Bligh, E. G. and Dyer, W. J. 1959. A rapid methods of total lipid extraction and purification. Can J Biochem Physiol 37, 911-917.

3. Bukkens. S., G. F. and 1996. The nutritional value of edible insects. Ecol Food Nutr 36, 287-319.

4. Folch, J., Lee, M. and Slane, S. G. H. 1957. A simple method for the isolation and purification of total lipids from animal tissue. J Biol Chem 226, 497-509.

5. Hwang, S. Y., Kim, Y. B., Lee. S. H. and Yun, C. Y. 2005. Preventive effect of a chafer, Protaetia brevitarsis extract on carbon tetrachloride-induced liver injuries in rats. Korean $J$ Oriental Med Physiol Pathol 19, 1337-1343.

6. Kim, H. G., Kang, K. H. and Hwang, C. Y. 2005. Effect of some environmental factors on oviposition and developmental characteristic of Protaetia brevitarsis and Allomyrina dichotoma. Korean J Appl Entomol 44, 283-286.

7. Lee, H. C., Hwang, S. Y., Jeon, B. H. and Lee, D. W. 2001.
Acute oral toxicity of Protaetia brevitarsis homogenate in rats. Korean J Oriental Med Physiol Pathol 15, 543-547.

8. Lee, J. H., Kim, N. K., Lee, D. Y. and Lee, C. H. 1999. Protective effect of selected amino acids and food extracts on ethanoltoxcity determent in ratee. Korean J Food Sci Technol 31, 802-808.

9. Nam, H. Y. and Lee, K. T. 2007. Analysis of characterization in commercial extra virgin olive oils. J Korea Soc Food Sci Nutr 36, 866-873.

10. Park, J. H., Kim, S. Y., Kang, M., Yoon, M., Lee, Y. I. and Park, E. 2012. Antioxidant activity and safety evaluation of juice containing Protaetia brevitarsis. J Korean Soc Food Sci Nutr 41, 41-48.

11. Yin, M., Ikenima, K., Arteel, G. E., Seabra, V., Bradford, B. U., Kono, H., Rusyn, I. and Thurman, R. G. 1998. Glycine accelerates recovery from alcohol-induced liver injury. $J$ Pharmacol Exp Ther 286, 1014-1019.

12. Zamora, R., Alba, V. and Hidalgo, F. J. 2001. Use of high-resolution ${ }^{13} \mathrm{C}$ nuclear magnetic resonance spectroscopy for the screening of virgin olive oils. J Am Oil Chem Soc 78, 89-94.

\section{초록 : 흰점박이꽃무지(Protaetia brevitarsis)의 일반성분 및 유해물질 분석}

정미연 · 권은영 · 황재삼 · 구태원 · 윤은영*

(농촌진흥청 국립농업과학원 농업생물부)

본 연구에서는 흰점박이꽃무지 유충의 식 - 약용으로써의 가능성을 제시하기 위해 영양성분분석 및 유해물질 검사를 실시하였다. 일반성분은 건량 기준 조단백질 함량이 $57.86 \%$ 로 매우 높았으며, 조지방 $16.57 \%$, 조섬유 $8.36 \%$, 조회분 $5.38 \%$ 로 구성됨을 확인하였다. 또한 불포화 지방산 중 혈압강하작용 및 여러 약리기전이 알려져 있는 oleic acid (omega-6)가 전체지방산 중 $60 \%$ 이상을 차지하고 있었고, linoleic acid (omega-6) 5.22\%, arachidonic acid (omega-6) $0.25 \%$ 함유되어 있었다. 유해물질의 분석 결과, 중금속의 일종인 수은이 $0.07 \mathrm{mg} / \mathrm{kg}$ 으로 존재하였으나 일반식품(어패류의 경우, $0.5 \mathrm{mg} / \mathrm{kg}$ ) 허용 기준치 이하의 미량인 것으로 확인되었으며, 병원성 미 생물인 대장균 $\mathrm{O} 157: \mathrm{H7}$ 과 살모넬라균은 검출되지 않았으므로 식용으로 사용하기에 문제가 없는 것으로 판단되 었다. 따라서 흰점박이꽃무지 유충은 고함량의 단백질과 필수아미노산 및 생체 내에서 합성할 수 없는 영양소들 을 다량 함유하고 있으므로 육류나 어류를 대신할 수 있는 대체식품으로 활용 가능할 것으로 판단되며 안전한 식품소재로의 기준 및 규격마련을 통해 식·약용으로 이용 가능할 것이라 기대된다. 